\title{
Study on the Right of Residents in Urban Residential District
}

\author{
Feng Guo*, Haocheng Sun, Yuye Chen and Jiangning Fang \\ School of Intellectual Property Rights, Nanjing University of Science and Technology, Nanjing, \\ Jiangsu, China
}

\begin{abstract}
Due to the lack of the urban household registration or property owner, many residents of urban residential areas in China have been in the state of lack of rights. The policy of "Equal rights for home tenants and owners" cannot play a practical role due to the lack of legal norms. "Home ownership" and "Right of residents" contain different contents. That is, "equal access to basic public services and social welfare of the place of residence, as well as the right to participate in decision-making, management and supervision of public affairs in residential communities and residential areas due to the fact of stable residence." The rights of the occupants is different from housing right and habitation right. The right of the occupants has not only legal basis, but also practical basis.
\end{abstract}

Keywords: Right of residents, Right of housing, Right of habitation, Equal rights for home tenants and owners

\section{Introduction}

In China's cities, about $30 \%$ of the resident population are from other countries, who need citizenship. In a few megacities, half of the non-native migrants have lived there for more than five years, and about 20 percent have lived there for more than 10 years.[1] Such a large number of non-native migrants live in local cities by renting, and the tenants of residential buildings are in the dilemma of "home ownership" for a long time, but unable to fully integrate into the local civil society and enjoy the rights and interests of residents[2]. On the one hand, according to the existing property management laws and regulations, as non-owner residents cannot participate in the owner governance activities of the residential community. On the other hand, according to the existing household registration policy, as unregistered foreign residents, they cannot equally enjoy the public welfare of the residence, nor can they participate in the grassroots democratic political activities of the local community. The fact that the occupant cannot change the separation of identity right and property right makes the public interest attached to the household registration and property right disappear because of the tenant's lease behavior.

In the report of the 19th National Congress of the Communist Party of China on strengthening the social security system, it was proposed to "accelerate the establishment of a housing system with multi-agent supply, multi-channel security and simultaneous rent and

\footnotetext{
* Corresponding author: fl-fl@,263.net
} 
purchase". Both rent and purchase simultaneously means to rent, and the tenant can best highlight the property that the house is used to live in. The implementation of the policy and the objective of the policy have become the watershed of the historical reform of housing system in China. However, there is no law to define the specific rights and interests of the same right of rent and purchase in China. The relevant laws and regulations aim to regulate the chaotic housing rental market and fail to focus on the series of rights changes caused by the lessee's renting. The legal essence of the same right of rent and purchase is to endow the lessee and the owner with the same rights in the field of basic public services [3], but the policy of the same right of rent and purchase cannot provide basic guarantee for the rights of residents. Under the constitutional spirit of respecting and protecting human rights, the rights and interests that residents should enjoy are always in a vague field.

\section{The proposal of the concept of "right of habitant"}

The inhabitant right refers to the right of residents to enjoy the basic social public service and social welfare equally, and to participate in the decision-making, management and supervision of the public affairs of the residential community and residential quarters due to the fact of stable residence. The right of habitant is different from the housing right and the habitation right. The existing theories and practices of the housing right and the habitation right are not applicable to the actual residents under a large number of residential lease contracts in China, that is, the residents are different from the subject of housing right and habitant right. The proposal of the concept of residence right is the scientific practice of the second generation of human rights of the United Nations in China's law. The content of the right of inhabitant is related to China's specific national conditions and social reality, which is more abundant and more difficult to define than the content of housing right.

As far as occupant rights are concerned, which is similar in nature to the right of housing in international human rights conventions but different in contents. The right of housing is the right of minimum living security. The right design is based on the protection of human rights and pays attention to the survival and development of natural persons. However, the right of housing which is subject to economic factors will be guaranteed differently according to the national conditions of different countries. So far, the right of housing has not been recognized and protected in China's law. In China's social environment, even if the right of housing is recognized, the right also needs to be converted in Chinese way in order to be compatible with the household registration system and housing system.

The right of residence is one of the usufructuary rights in other property, which is used to adjust the housing usufruct relationship between equal civil subjects. From the perspective of the protection of real right, the right of habitant is based on the protection of the basic right of residence of the right holder, and it does not concern the right holder's participation in other aspects of citizen's life. Accordingly, the protection of the right of habitant focuses on some aspects, which cannot cover all the rights and interests of the oblige. Therefore, other rights protection systems and theirjoint functions are needed to guarantee the citizens' enjoyment of grassroots democratic rights and social welfare rights.

Thus, the right of housing and the right of habitation cannot abstract the right of habitation and form the complete content of the right of habitation. The concept of habitant right is put forward due to the necessity of extension of the above theory and the urgency of habitant right protection.

The right of habitant means the right enjoyed by the habitant. From the normative analysis of the right, the subject of the habitant's right is the actual habitant in the migrant population, without the local household registration, but it has a relatively stable living fact. By paying rent or property fee, they have the public interests and services attached to the buyers or property owners. In fact, the residents get a free physical and geographical space, the 
residence and activities are not temporary or temporary for special purposes, but relatively long-term living, working and living in the local area consumption, entertainment and labor.

The object of the habitant's right, that is, the object of the inhabitant's right, is not limited to the rented house, not limited to the autonomy of the grassroots mass organization, but also includes the inheritance of the public interest enjoyed by the property owner because of the stable living fact. The legalization of the concept of habitant rights not only enables the majority of residents to realize the basic housing goal of "home ownership", but also enables them to live and work in peace and contentment [4]. The content of the right of habitant includes many aspects. At present, the trend of "renting and purchasing simultaneously" in China's housing reform policy can reflect part of the contents of the residents' rights, and the slogan of "renting and purchasing the same rights" can better reflect the value orientation of the residents' rights. The core of habitant rights is the non-discrimination of identity, the indifference of rights and the equality of status. The right of inhabitant is similar to the second generation of human rights "housing right" proposed by the United Nations. However, due to the household registration system and housing system in China, the right of habitant has its own special features. With the development of the social system, the content of the right of residence will change. In terms of China's current national conditions, the right of residence specifically covers the following aspects: children's education, medical security, employment support, pension services, social welfare, and political participation [5].

The right of the inhabitant is relative to the place of residence. When a natural person changes his residence, it involves the elimination of the right of inhabitant. The acquisition of the right of inhabitant relative to the new residence is conditional, that is, in line with the principle of "the right to go with the place of residence". When a natural person migrates the original habitat to a new place to live, he will lose his original inhabitants, not shall enjoy the right of residents both at the same time, residents can only obtain the actual residence of the public service and social welfare, to prevent improper occupy and waste of public resources.

\section{Legal principle of the right of habitant}

The right of habitant is separated from the right of housing and the right of habitation, which not only has the unique right connotation, but also has the practicallegal principle.

First of all, the right of habitant accords with the legitimacy of human rights protection. One of the important reasons for the legitimacy of the establishment of the system of residents' rights is that it has further improved the protection system of people's right to subsistence and development. From the perspective of human rights protection, the function of habitant right system is to protect people's right to survival and development. The system of habitant rights contains the protection of the subject's right to subsistence and development, which is in line with the principle of minimum living guarantee of housing right in the United Nations Convention on human rights and the interests of the usufructuary right holders in the property law. The right of habitant can well reflect the uniqueness of the right of development, in the implementation by identity, eliminating property gives residents shall be equal opportunities for development. The prerequisite for the existence of the right of habitation is the guarantee of freedom of residence, the most representative of which is the provision of article 22 of the Japanese Constitution: "[freedom of residence, migration and choice of occupation, freedom of moving to a foreign country and seceding from nationality] a. Everyone has the freedom to live, to move and to choose his occupation, so far as it is not contrary to public welfare. $b$. The freedom of any person to emigrate or to renounce his nationality shall not be infringed." The establishment of the system of residents' rights can make the residents better survive in their residence, and obtain the development conditions which cannot be obtained by the household registration and housing system before. 
Secondly, the right of residence conforms to the ultimate goal of the development of social welfare system. Different from the minimum living guarantee nature of housing right and the real right interest to make the best use of everything pursued by the right of residence, the right of habitant has jumped out of the right level of the minimum living guarantee and has a higher level of social right demand on the basis of the exercise of usufruct. The subject of the right of habitant does not choose to live in a city because of poverty, but chooses to live in a development place in pursuit of a better life goal, which is consistent with the goal of beauty, happiness, equality and justice pursued by social welfare policies. The emphasis on Residents' rights means opposing social exclusion and promoting social integration. It requires the government to use public power to intervene in the unfair distribution of public resources and eliminate the differences in interests of residents in obtaining basic public services provided by the government due to their status.

Finally, the right of habitant embodies the objectivity of the legal value. This can be seen from three aspects. Firstly, the system of the right of residents has objective justice value. Since ancient times, the justice value of law is often regarded as not only the highest value of law, but also the highest value of human society. The system of habitant rights creates new right distribution way, namely by giving corresponding conditions or any natural person having a corresponding duty in a particular region of the identity of the residents, and bases on this identity, they can enjoy various public services and rights that are convenient for them to continue to live and contribute to the development of the region, so as to promote local development. Secondly, the occupant right system has the objective value of freedom. The ultimate goal of the right to create residence is that the natural person who has acquired the residence status can enjoy the corresponding freedom. The system of habitant right is based on the premise and purpose of freedom, and it is also the way to realize freedom. Thirdly, the occupant right system has objective and equal value. Equality, like freedom, is the core value of modern society. Right of habitant breaks through the shackles of property right system and household registration system, which enables the migrant population in the same area to enjoy the same civil rights of local residents, and solves the problem of residents' right demands caused by the separation of status right and real right for a long time.

\section{Basis for the realization of habitant rights}

The history of the development of human rights provides a practical basis for the construction and operation of the legal system of residents' rights. As mentioned above, the right of resident is similar to the right of housing in international human rights covenants. The concept of housing right originates from the expression of "the right to adequate housing" in international human rights covenants, as shown in article 11, paragraph 1, of the International Covenant on Economic, Social and Cultural. Rights: "the states parties to the present Covenant recognize the right of everyone to an adequate standard of living for himself and his family, including adequate food, clothing and housing and to the continuous improvement of living condition." On December 12, 1991, the United Nations Committee on economic, social and cultural rights held that the right of housing is an important right in social rights. In order to solve the problem of people's vague understanding of the right of housing, it committed itself to providing a basis for a unified understanding, and adopted General Comment No.4(1991) The Right to Adequate Housing, namely The General Comment No. 4: The Right to Adequate Housing. The right of housing refers to the right to be housed and to live in dignity. The most critical thing is that the right of housing is the right of the Government, which has the obligation to provide citizens with suitable housing and to improve their living conditions. Under this theory of human rights, the content of welfare doctrine contained in the right of inhabitant, like economic and social rights, depends on the state's action, that is, the realization of rights is the obligation of the state. 
Under the framework of international human rights and protection under the framework convention, the right of housing cannot be ignored as a basic human rights, such as Spain, Portugal, Switzerland, Finland, Russia, South Africa and other countries have confirmed in the constitution, making special housing or legal right to affordable housing, such as the United States, Germany, Australia, Japan, Singapore and other countries. Although China's constitution does not explicitly mention the right of housing, the constitutional principle of respecting and protecting human rights and the fact that China is a state party to the International Covenant on Economic, Social and Cultural Rights makes it possible for the right of housing to be incorporated into the Constitution and for laws on housing security to be enacted, which is also the need for China to fulfill its international obligations. The legislative practice of the above countries provides experience for the construction of the legal system of the right of habitant. The right of inhabitant, which is related to the right of housing, is also facing the opportunity of legalization. Some scholars believe that "the basic right status of housing right should be confirmed at the constitutional level, so as to form an objective legal value order that standardizes the legislation, administration and judicature."[2]

However, at present, the judicial organs cannot directly apply the basic rights of the Constitution in our country. That is to say, the court cannot accept constitutional rights litigation [6]. However, the newly added right of habitation in the civil code of China provides the legal and material basis for the habitant's right. The right of residence promotes the convergence and development of traditional property rights and modern residential rights, further improves China's property law, more conducive to meet the people's basic living security, provides a legal system guarantee for solving housing problems with multi-level property rights structure [7], and provides a legal basis for the protection of the rights of habitant.

In practice, the right of habitant system is mainly applicable to the economic assistance of divorce, the needs of pension security, and the housing problems of minors. However, after improvement, the purpose of establishment of the right of residence has also been extended from basic living needs such as support and maintenance to housing investment, which has also played a positive effect on commercial activities. The residential right system is a breakthrough and extension of the current legal norms. The expansion of its scope of application is in line with the objective needs of social development. Undoubtedly, the right of habitation has become an important way to realize the right of habitant, which provides a realistic material basis for the protection of the right of habitation. There are conflicts between the right of habitant and the right of habitation. The starting point of the right of inhabitant is the interest of human development, which is different from that of the right of abode.

The improvement of grassroots social governance system and governance capacity can provide a good environment for the realization of habitant' rights. The residents enjoy the right of inhabitant because of their actual residence, which not only inherits the democratic rights of the owners in the community, but also obtains the public resources and social welfare enjoyed by the residents of the residence. However, the realization and guarantee of all this cannot be achieved without the high recognition and active implementation of grassroots autonomous organizations. The Fourth Plenary Session of the 19th Central Committee of the Communist Party of China proposed "to build a new pattern of grassroots social governance and improve the institutionalized channels for the masses to participate in grassroots social governance." It can be seen that the current society has changed from the "management" mode at the grass-roots level to the "governance" new situation. The community assumes the responsibility of social security and public services at the bottom level. As the grass-roots organization for the implementation of the government's livelihood policies, residents' committee should become a powerful organization for the protection of residents' rights. "For the society, the autonomy of the business council is the first priority, 
which is endowed by the society with high expectations of safeguarding the rights and interests of owners, promoting grassroots democracy and building civil society, thus gaining high social legitimacy."[8] As an autonomous organization of the owners of urban residential communities, the owners' committee can directly reflect the public opinion and convey the valuable opinions of the residents of the communities on the protection of the residents' rights. Through the cooperation of the residents' committee and the industry committee, the residents can get rid of the shackles of household registration and owners' identity, and truly realize the residents' rights.

\section{Conclusion}

Since World War II, the practice of the second generation of human rights "right of housing" of the United Nations, and the implementation of the current "renting and purchasing simultaneously" policy in China, have made the legal sense of the concept of occupant rights precipitate. Through the definition, analysis and deconstruction of the concept of "right of habitant", it is proved theoretically that the right of habitant is independent of the right of civil residence. The legitimacy and rationality of the construction of rights of habitant can not only solve the shortage of housing policy, make the same right of renting and purchasing feasible, but also effectively promote the equalization of basic public services, boost the legalization, and solve the new contradictions aroused by social injustice in the new era.

\section{Acknowledgements}

This research was financially supported by: the National Natural Science Foundation of China-- The Rule-following Behavior of Owners and its Impact on the Governance of Urban Residential District in China (71774082) and JiangSu Undergraduate Training Program for Innovation and Entrepreneurship (201910288159Y).

\section{References}

1. Y. Qu, G. Zhang. What are the top priorities in the 14th five years plan? Experts outline the key points for you [EB/OL]. People's Daily ,2020-08-28[2020-09-04]. http://www.people.com.cn/BIG5/n1/2020/0828/c32306-31841145.html.

2. J. Liu, Y. Xing. Study on the Realization Mechanism of Public Service Equalization between Buyer and Tenant, SER, 35 (05), 51-59, (2018).

3. H. Xie. Legal Implications of the same Right of Lease and Sale and its Realization Approaches, 26 (27), 100-102, (2017).

4. Y. Zhang. Policy objectives and legal structure of China's Housing Leasing Law under the same right of renting and purchasing, 63 (16), 86-89, (2019).

5. J. Chen, Y. Wu, The Possible Conflict between the Housing Rights and the Rights to Public Services Availability in the Process of "Equal Rights between Buyer and Tenant"- Renting for Living or Renting for Rights, 63 (2), 44-56, (2019).

6. H. Huang, Y. Pan. Discussion on housing right and its legislative guarantee, 35 (01), 82-84, (2013).

7. H. Quan, JJU. Discussion on the system of habitation in The Real Right of Civil Code, 39 (02), 119-121, (2020).

8. L. Xiao. The Asymmetric Legitimacy: A Comparison between Resident's Committee and Homeowners' Committee, 2 (6), 58-68, (2014). 